\title{
ks. Jerzy Jastrzębski, Paragraf w sercu. Kardynat Stefan Wyszyński o miłości i sprawiedliwości społecznej, Wydawnictwo UNUM, Kraków 2014, ss. 431 \\ DOI: http://dx.doi.org/10.15633/acan.1065
}

Powojenne dzieje Polski są niezwykłym wycinkiem jej wielorakich zmagań w całej ponadtysiącletniej historii. To wyjątkowe nagromadzenie nowych jakości i nadziei. To wielość i bogactwo osób oraz wydarzeń. Nie można jednak rozpatrywać ich w rozdzielności, oderwanych od siebie, ale należy je traktować jako wzajemnie oddziałujące na siebie fenomeny i współtwórcze rzeczywistości.

Ważnym komponentem tych wydarzeń jest życie i działalność sługi Bożego kard. Stefana Wyszyńskiego, arcybiskupa metropolity gnieźnieńskiego i warszawskiego, prymasa Polski. Jego szerokie zaangażowanie społeczne, kulturowe i religijne stanowi wyjątkowy wątek powojennych dziejów Kościoła w Polsce. Jego postać, nauczanie i działanie odcisnęły na Kościele niezatarte znamię. Oczywiście bogactwo to jest różnie odbierane i interpretowane czy rozeznawane i oceniane. Jest to bowiem ciągle żywa rzeczywistość, realistycznie odbierana.

Autor prezentowanej rozprawy jest doktorem nauk teologicznych. Aktualnie pracuje w Wyższym Metropolitalnym Seminarium Duchownym w Warszawie, które jest afiliowane do Papieskiego Wydziału Teologicznego w Warszawie, gdzie wykłada homiletykę i retorykę. Ks. Jerzy Jastrzębski jest znanym badaczem życia i nauczania kard. Stefana Wyszyńskiego.

Książkę otwierają emocjonalna dedykacja dla rodziców (s. 5) oraz różnorodne podziękowania (s. 7).

Zasadniczy korpus treściowy zapoczątkowany jest dość obszernym wstępem (s. 9-20). Z kolei całość studium podzielono na pięć rozdziałów, a rozdziały z kolei na inne mniejsze, dwustopniowe zbiory.

Podstawy troski Kościoła o mitość i sprawiedliwość społecznq to tytuł pierwszego rozdziału (s. 21-83). Autor wskazuje na Wielką Nowennę jako przejaw troski Kościoła o wieczność i doczesność, a więc jej genezę, program i znaczenie. Zresztą sama misja Kościoła wpisuje się w obie kategorie. Kościół jest zawsze głosicielem sprawiedliwości pochodzącej od Boga. Wreszcie podjęto próbę zestawienia miłości społecznej i sprawiedliwości społecznej.

Drugi rozdział opatrzony został tytułem Troska Kościoła o miłość i sprawiedliwość społecznq wobec człowieka (s. 85-142). Najpierw ukazano godność człowieka jako wezwanie do miłości i sprawiedliwości wobec osoby ludzkiej. 
Szczególnym przykładem człowieka miłującego i sprawiedliwego jest Maryja. Przywołano także przykłady: św. Józefa Rzemieślnika, św. Franciszka z Asyżu, św. Klary, św. Jolanty, św. Stanisława Kostki, św. Pawła Pustelnika, bł. Władysława z Gielniowa, bp Stanisława Adamskiego i Zofii Szczuki z Lasek Warszawskich.

Kolejny rozdział studium ks. Jastrzębskiego jest zatytułowany Troska Kościoła o miłość i sprawiedliwość społecznq w rodzinie (s. 143-218). Omówiono w nim Boży zamysł rodziny, zobowiązania spoczywające na rodzinie, obowiązki małżonków, rodziców, dzieci i młodzieży.

Temat Troski Kościoła o miłość $i$ sprawiedliwość społecznq $w$ narodzie podjęty został w rozdziale czwartym (s. 219-304). Autor ukazuje Kościół jako sługę narodu. Wymowny jest tytuł jednego z paragrafów: Maryja Matka narodu polskiego (s. 256-265). W rozdziale scharakteryzowano zobowiązania spoczywające na niektórych przedstawicielach narodu: prawnikach, kapłanach, pracownikach służby zdrowia, pedagogach, ludziach nauki oraz pisarzach i dziennikarzach.

W ostatnim rozdziale poruszono zagadnienie Troski Kościoła o mitość i sprawiedliwość społeczna w państwie (s. 305-386). Kościół - przy określonych warunkach - może być współpracownikiem państwa. Autor podał wybrane normy regulujące współpracę pomiędzy Kościołem i państwem: poszanowanie religii i tradycji chrześcijańskiej, klasyczną koncepcję i wykładnię prawa, konieczność istnienia i odpowiedniego użytkowania własności prywatnej oraz gwarancję godziwego bytu - sprawiedliwą zapłatę. Wreszcie wskazano na obowiązki obywateli wobec państwa: służbę wojskową, płacenie podatków, posłuszeństwo wobec władzy, opór wobec władzy i wdzięczność wobec władzy.

Całość zamyka zakończenie (s. 387-395). Zamieszczono jeszcze bibliografię (s. 397-424), wykaz skrótów (s. 425) i spis treści (s. 427-431).

Oto jeszcze jedno studium nad myślą teologiczną i społeczną kard. Stefana Wyszyńskiego. Ma ona w sobie także wiele elementów odnoszących się do prawa kanonicznego i cywilnego, przynajmniej na płaszczyźnie ducha czy inspiracji - przecież z wykształcenia Prymas Tysiąclecia był kanonistą. Oto zatem jeszcze jedna próba analizy ważkiego zagadnienia miłości i sprawiedliwości społecznej, które miało szerokie oddziaływanie nie tylko w okresie Wielkiej Nowenny. To przesłanie bowiem owocowało na dalsze lata posługi Prymasa Tysiąclecia. Zresztą stał się on swego rodzaju ambasadorem tej problematyki, która wpisuje się twórczo w szerokie nauczanie społeczne Kościoła. Także dziś warto do tego nauczania odważnie sięgać.

Słusznie „autor żywi nadzieję, że lektura tej pracy pozwoli Czytelnikowi dostrzec zarówno wielką miłość Prymasa Tysiąclecia do narodu polskiego, jak 
i oryginalność oraz aktualność jego kaznodziejstwa" (s. 20). Trzeba zawsze pamiętać, że posługa ewangelizacyjna kardynała Wyszyńskiego była charyzmatycznym dziełem, które wykraczało ponad rachuby czasowe. Zawsze był to jednak dar dla innych, choć może czasem spotykał się z krytyką czy niezrozumieniem, zwłaszcza niektórych środowisk. Dziś - z perspektywy czasu - jeszcze łatwiej dostrzega się geniusz jego przepowiadania oraz jego aktualność. Zresztą dobitnie potwierdził to, i to wielokrotnie, św. Jan Paweł II.

Słusznie stwierdza ks. J. Jastrzębski: „Mimo upływu czasu nauczanie pasterskie Prymasa Tysiąclecia wciąż cieszy się niesłabnącym zainteresowaniem. Kardynał Stefan Wyszyński obdarzony był bowiem niebywale wyrazistą świadomością swojej misji i posłannictwa w kierowaniu Kościołem w Polsce" (s. 9). Tym oczekiwaniom sprzyjał także czas po II wojnie światowej i ówczesne różne okoliczności, wydarzenia oraz osoby, nie tylko w Polsce, ale i w Europie oraz na świecie. Prymas Tysiąclecia wyrósł na lidera troski o narody, ich kulturę i dziedzictwo religijne, uciemiężone totalitaryzmem komunistycznym.

Dobrze, że autor jasno wskazuje, że „celem niniejszej pracy było przybliżenie nauczania pasterskiego Prymasa Tysiąclecia w okresie Wielkiej Nowenny na temat miłości i sprawiedliwości społecznej" (s. 387). To był wyjątkowy czas, który m.in. dzięki przepowiadaniu kard. S. Wyszyńskiego okazał się niezwykle owocny. Faktycznie ta tematyka okazała się także szczególnie nośna w ostatnich latach jego posługi. Właśnie rodzenie się nowych nadziei, zrywów demokratycznych okazało się nową jakością, w której nieobojętne było całe przepowiadanie Prymasa Tysiąclecia.

Trzeba zauważyć, że tytuł książki nie odpowiada tematowi rozprawy, której treść jest tutaj prezentowana: Troska Kościoła o miłość i sprawiedliwość społecznq w nauczaniu pasterskim Kardynała Stefana Wyszyńskiego w okresie Wielkiej Nowenny (1957-1966) (s. 14). Wydaje się, że autor winien to wyjaśnić. Z drugiej strony wiadomo, że przy rozprawach doktorskich zazwyczaj szuka się atrakcyjnych tytułów dla edycji książkowych.

Wielkim problemem dla badań nad spuścizną Prymasa Tysiąclecia są teksty nieautoryzowane, pozostające w maszynopisie Zbiór kazań Prymasa Tysiąclecia (s. 409-410). Do tego dochodzi jeszcze problem dostępności zbioru Kazania i przemówienia autoryzowane Prymasa Polski. W kontekście obu zbiorów pojawia się pytanie o kompletność Dziet zebranych. Można przypuszczać, że w najbliższej perspektywie trudno oczekiwać, aby coś zmieniło się w tym względzie, a rodzi to liczne pytania natury edytorskiej. 
Warto zauważyć, że każdy rozdział ma krótkie wprowadzenie oraz syntetyczne podsumowanie. To dobry zabieg, ułatwiający lekturę studium. Wstęp i zakończenie są klasycznymi elementami studium dyplomowego.

Kardynał Stefan Wyszyński nigdy nie był metropolitą gnieźnieńsko-warszawskim (s. 387). Warto przy kard. Józefie Glempie podać, iż - podobnie jak jego poprzednik - był arcybiskupem gnieźnieńskim i warszawskim, do bulli Jana Pawła II Totus tuus Poloniae populus z dnia 25 marca 1992 roku (s. 394).

W bibliografii chyba niepotrzebnie przywołano konkretne dokumenty Soboru Watykańskiego II i oddzielnie całego zbioru - wystarczyłoby to pierwsze (s. 410). Miejscem wydania Listów pasterskich Episkopatu Polski 1945-1974 nie był Paryż, lecz Paris (s. 411). Występują różnice w opisach w bibliografii i przypisach (s. 11415). W bibliografii nie zawsze zachowano układ alfabetyczny (s. 421). W Słowniku społecznym czy Stowniku teologii biblijnej należało podać hasła i ich autorów, gdyż stanowią one często zwarte traktaty (s. 423). Pominięto w bibliografii imiennie tekst Leszka Kuca, który ma dwie edycje, a przywołano ogólnikowo tylko książkę W kierunku człowieka, w której on także jest zamieszczony (s. 13, 424).

Studium warszawskiego badacza jawi się jako kolejna szansa na spotkanie z nauczaniem kard. Stefana Wyszyńskiego. Ciągle istnieje potrzeba takich badań, które - oddalone już w czasie - przepowiadanie Prymasa Tysiąclecia czynią stosunkowo aktualnym i nadal twórczym. Badania te są nie tylko refleksją o charakterze historycznym. To zawsze dotykanie realizmu trwania i bogactwa dalszego jego oddziaływania.

Myśl Prymasa Tysiąclecia wyraża nadal żywą troskę o Kościól, ojczyznę i wszystkich Polaków, także żyjących poza granicami kraju. To jest szerokie rozumienie owej zbiorowej rzeczywistości narodu, która była bliska kard. Wyszyńskiemu i często obecna w jego nauczaniu. To wołanie o to zatroskanie motywowane odpowiedzialnością oraz wiarą. Cała jego posługa była tak szeroko adresowana i często niedająca się ująć w pewne schematy czy wzorce.

Podjęte zagadnienie miłości i sprawiedliwości społecznej ma szerokie odniesienia. Autor określa to zagadnienie terminem „troska”. Zatem to pewne uczucie niepokoju wywołane trudną sytuacją lub jej przewidywaniem, realną możliwością zaistnienia takiej sytuacji. Do głosu dochodzi także dbałość o te dwie wartości, zabieganie czy troszczenie się o nie oraz głoszenie ich. 